Human, Social, and Intellectual Capital in the COVID-19 Era: Establishing the Agenda. Framing, Plausibility, and Verifiability in the Repositories

Capital humano, social e intelectual en la era COVID-19: establecimiento de la agenda, encuadre, plausibilidad y verificabilidad en los repositorios 



\title{
Human, Social, and Intellectual Capital in the COVID-19 Era: Establishing the Agenda. Framing, Plausibility, and Verifiability in the Repositories
}

\section{Capital humano, social e intelectual en la era COVID-19: establecimiento de la agenda, encuadre, plausibilidad y verificabilidad en los repositorios}

\author{
Cruz García Lirios \\ Universidad Autónoma del Estado de México, México \\ cgarciali@uaemex.mx (http://orcid.org/o0oo-0002-9364-6796) \\ Received: 25-07-2021 / Accepted: 04-11-2021 \\ https://doi.org/10.1880o/conexion.202102.006
}

\section{PALABRAS CLAVE / KEYWORDS}

Heads of household, social work, entrepreneurship, specification, mode / jefes de hogar, trabajo social, emprendimiento, especificación, modo

\section{ABSTRACT}

The health and economic crisis caused by the SARS CoV-2 coronavirus and the COVID-19 disease has accelerated the emergence of an informational economy focused on the use of electronic networks. The impact of this scenario on education led to the transition from the traditional classroom to the electronic whiteboard. The objective of the present work is to analyze the relationships between human, social, and intellectual capital. A model showing the prevalence of human capital creation-as indicated by data processing in the virtual classroom and self-management of knowledge-was established.

\section{RESUMEN}

La crisis sanitaria y económica provocada por el coronavirus SARS CoV-2 y la enfermedad COVID-19 han acelerado el surgimiento de una economía de la información centrada en el uso de redes electrónicas. El impacto de este escenario en la educación propició la transición del aula tradicional a la pizarra electrónica. El objetivo del presente trabajo fue analizar las relaciones entre capital humano, social e intelectual. Se estableció un modelo en el que se aprecia el predominio de la formación de capital humano indicado por el procesamiento de datos en el aula virtual y la autogestión del conocimiento. 


\section{Human, Social, and Intellectual Capital in the COVID-19 Era: Establishing the Agenda. Framing, Plausibility, and Verifiability in the Repositories}

As of December 2020, 17 million people have been infected by the SARS-CoV-2, 9 million have contracted the disease, and 700,000 deaths have been reported globally (Hernández et al., 2020). In Mexico, 500,000 people were infected, 300,000 fell ill, and 50,000 died. In this scenario of risk, uncertain situation, and health contingency, the education of human and intellectual capital is focused on the virtual classroom (García, 2020). Unlike the traditional classroom where the stage is controlled by the teacher, the electronic classroom technology defines the type of communication between the parties involved.

The differences between the figures for infected, sick, and dead individuals in countries with a similar level of development and population can be observed in risk communication and management (Juárez et al., 2020). In this sense, the establishment of the agenda allows us to observe the differences between the rulers and the ruled. In other words, while the State considers distancing and confinement a priority, citizens insist on working to compensate for unemployment or informality. In this way, the review of the literature will reveal the topics on the agenda of the establishing differences and anticipating risk scenarios for the public administration and for the citizens.

The objective of this study is to specify a model for the study of social entrepreneurship in heads of household. The variables that made it possible to systematize the determinants of the entrepreneurship trajectories were extracted from a review of the existing literature.

How is the capital creation process reported in the literature from 2018 to 2020 in international repositories, considering the prestige of the source?

The premises that guide this research suggest that significant differences prevail between the public health administration and users regarding the establishment of an agenda and the framing of the information disseminated in the media and networks, as well as its effects on decisions and actions of people (Bustos et al., 2020). More specifically, it is about the influence of images of infection, disease, and death from COVID-19 and its impact on academic, professional, and work training, as well as the incidence of data and its consequences on the skills of comparing sources and content related to COVID-19.

The hypothesis that guides this study refers to the fact that the determinants of the creation of intellectual capital are different in the traditional classroom with respect 
to the virtual classroom, as well as among users, considering their acceptance, adoption, and compatibility of the technology. In this way, the theoretical, conceptual, and empirical frameworks related to the creation of intellectual capital in risk scenarios and uncertain contingencies are presented (García, 2018). The methodological decisions to address the phenomenon are described below and the corresponding diagnosis is presented (Carreón, 2021). Discussion of the findings with other works is included and the implications in the virtual classroom are reflected upon.

\section{Theoretical Framework}

\section{Theory of the Establishment of the} Agenda and Human, Social, and Intellectual Capital

The establishment of the public agenda is a phenomenon of risk communication that consists of the dissemination of issues such as the distancing and confinement of people, instruments of containment and mitigation of the pandemic (Zallas et al., 2020). In this sense, the conferences and statements of public health officials build a state agenda that is contrasted with the research agenda of the experts. In the case of the literature published during the pandemic, a scientific and research agenda is established that may coincide or contravene the provisions of the State. Thus, in terms of communicating the risks of COVID-19, the literature suggests that stigmas are estab- lished for doctors, nurses, social workers, and police who work in health centers and hospitals. Meanwhile, citizens process this information in the media and electronic networks such as Facebook, Twitter, YouTube, WhatsApp, Instagram or TikTok. Although the state or scientific agenda is widely disseminated, the reception of its issues is processed according to the opinions of the people, who assume that the government is responsible for the management of the pandemic. In this way, the number of infections, sick individuals, and deaths is attributed to the State rather than to the public. Even selfcare and health promotion are attributed to health institutions.

In contrast, from the theory of human capital, health promotion may be attributable to the State, but self-care is an indicator of personal development, as well as a distinctive feature of academic, professional, and work training. If students, professionals, and workers develop academic or work skills, they are obliged to prevent accidents and illnesses based on consumer decisions and in line with the internal strategies or programs of companies and institutions (Bolivar et al., 2021). In that order of ideas, the theory of intellectual capital emphasizes the capacities, abilities, and knowledge that not only allude to the risks of contagion, illness, or death, but, from which, processing allusive data can be anticipated. In addition, beyond risk prevention, there is health-oriented behavior that can be 
compatible with government strategies to reduce spending. Both categories: human capital as the development of academic and work capacities, and intellectual capital as the development of information skills and knowledge, contravene the state risk communication. This is so because the State legitimizes its intervention by considering citizens as recipients of its health policies. In contrast, the scientific community tries to reveal an agenda of differences between the actors, but oriented towards a common origin and purpose, such as health.

It is scientific studies that warn of the defenselessness of citizens as government strategies of confinement and social distancing intensify, as well as demonstrations of risk areas, exposure to contagion, and the probability of illness and death (Bermudez et al., 2019). Far from considering data on risks, infection, disease, and deaths, citizens build their agenda from the type of state or scientific communication. The more the data on COVID-19 intensifies, the more hopelessness is generated in the audiences. In fact, speeches about the end of humanity and the need to compensate for that expectation with hedonistic actions are exacerbated. Consequently, the study of social capital acquires a health dimension linked to hopelessness rather than risk prevention. The learned hopelessness theory suggests that the bombardment of information fosters inaction as the risk event approaches er risk events as plausible if they are close to them and implausible if they are distant. In contrast, the proximity of the risk encourages immediate action whenever the event is unavoidable. If there is a possibility that the event is not significantly risky, it will lead to weak or absent action.

The principles that guide rational choice lie in tastes and preferences, crystallizing the objectives of the actors (Morales et al., 2020). Therefore, before making any binding preferred strategy decisions, gather information that will determine the choice. If individuals prefer to have an indeterminate number of tastes, objectives, and goals, then their preference will no longer depend on their capacity for choice and action (García \& Bustos, 2021). Therefore, they act in a non-rational way. Rational choice theory also warns that a decision is the result of an estimate of the costs and benefits of trying, regardless of its degree of significance (Quiroz et al., 2020). This is a utilitarian dimension in which controlling a situation to establish a favorable balance of benefits versus costs will determine the choice. More specifically, benefits and costs translate into a ratio of risk, effort, and reward (Garcia, 2021). This means that a choice must be rational when risks and efforts are minimal if the rewards are greater.

On the other hand, when the recognition of an effort and risk does not live up to expectations, then the choice has not been completely rational and, rather, it 
approaches an irrational dimension if the risks and efforts are increasing and intensifying with respect to the absence of rewards (Korstanje, 2020). This is because the individual is committed to the risks that will be triggered by profit expectations (Quintero et al., 2021). The integration of each of the variables represents a series of paths in which the correlations explain each choice (García Lirios, 2020). The rational choice explains in general terms the process by which preferences are the determining factor for other factors that generate information or create a climate of certainty when deciding and acting accordingly (Garcia, 2020). To the extent that such information is available, accessible, and actionable, then the rational choice will emerge as an option, but as ambiguity proliferates, then a non-rational decision will be generated with irrational consequences.

However, when the information is not available or is very abstract, the rational choice is replaced by a stricter option toward people's culture, values, and norms with respect to a contingency for which some precedents are not known, but the people always react in the same way (Sánchez-Sánchez, 2019).

\section{Studies on the Establishment of the Agenda and Human, Social, and Intellectual Capital}

Studies on the establishment of the agenda and social, human, and intellectual capital emphasize the relationship between the rulers and the ruled with respect to risk events (García-Lirios, 2021). In this way, it is known that the communication of the mitigation or containment of the pandemic favors academic, professional, and labor training, but not in the effective way that a public and common agency could mean among the parties involved, the political and social actors, as well as the public and private sectors.

Studies of risk communication and academic, professional, and labor training have demonstrated the emergence of social hopelessness in the face of the intensive dissemination of infection, disease, and death, but very little is known about the impact that scientific literature has on public policies and the self-care of people (García et al., 2021). These research has shown a consonance between the diffusion of the distancing and confinement of people with respect to contagion, disease, and death, but not with regard to the inclusion of risk communication in the decisions of social, human, and intellectual capital creation. In other words, defenselessness is a response to risk, but it does not imply a common agenda between the parties involved.

The studies of the establishment of the agenda and the social, human, and intellectual capital have advanced in three phases: the agenda as distinctive themes of the political and social actors, the framing of the media, and the impact of infor- 
mation on audience consumption. This is the case of the conferences on COVID-19 held by the Mexican State. The agenda focused on the asymmetries between detection tests and confirmed cases of infection by coronavirus SARS CoV-2 and/or patients by COVID-19. An event of national coverage with effects on audiences that instructed about distancing and social confinement.

If the first studies allude to the frequency of data issued by health institutions on compliance with the confinement and social distancing rules, the studies on framing advanced towards the dissemination of information on two types of audiences: audiences oriented by plausibility and audiences driven by informative verifiability (Carreón et al., 2021). It is about the plausibility strategy that consists of the prevalence of images and that are directed towards audiences that look for sources in line with their normative principles. Faced with informative credibility, media verifiability is built relying on comparing data from different sources to investigate differences and establish a specialized and updated agenda of cases of infection, disease, and deaths from COVID-19.

However, the agenda and the framing are instances that paved the way for researching the impact of the media and networks on human behavior (Hernandez et al., 2021). If the establishment of issues such as distancing and confinement were ori- these strategies because they consider that the State should guarantee the health of citizens, then the effect of communication styles would warn of risk amplification scenarios. This is the case of political actors who dismissed the pandemic and fostered in audiences a sense of normalcy without restrictions, but with incalculable effects on the rate of infection, disease, and number of deaths. In contrast to this communication of plausibility and catastrophic effects on audiences, communication for the verifiability of data generates risk prevention, but based on the hopelessness of the audiences. This is so because the comparison of data from different sources supposes a comprehensive panorama that guides decisions and actions towards prevention whenever the audiences consider that they are in control of a risk situation.

If the rational choice is being developed centered on preferences based on available information to determine tastes and objectives, the forward-looking attitude suggests that the absence of information generates uncertainty that determines the aversion to risk or the renunciation of certain gains and appetite for risk when losses are imminent (Bermúdez et al., 2019). Thus, utility, profit, or happiness crystallize in profit or loss, bypassing the rational choice process and legitimizing an irrational choice (Garcia, 2021). Therefore, a prospective disposition is more than a mere decision, it lies in the attitude and expectation of risk or certainty of gains 
and losses in the immediate future. In that sense, retrospective is an attitude that has the same relationships but compared to the previous one (Bustos et al., 2019). The prospective attitude is a hinge between rational choice and reasoned action (Aguilar et al., 2019). The surrounding information in the media would lead to rational choices if the audiences could access all the content. In contrast, the reasoned action warns that motivation, attitudes and intentions are enough to prevent a behavior promoted in the media. Each of these theoretical and conceptual frameworks bases its scope and limits on the availability of information, if the individual is capable of assuming an attitude, making a decision or taking an action that corresponds to the available information and the representation that it has.

\section{Modeling the Establishment of the Agenda and Human, Social and Intellectual Capital}

From the theoretical and empirical frameworks on the agenda, the setting, the plausibility, and the verifiability of the pandemic, confinement and distancing, it is possible to model the creation of social, human, and intellectual capital in a risk situation such as that expressed ad infection, disease, and death that the literature has reported from December 2019 to August 2021.

In this way, the study of the agenda, framing, plausibility, and verifiability in the literature published during the pandemic supposes a creation of the social, human, and intellectual capital from images and data (Bustos et al., 2019). This is so because the media and networks disseminate the topics of the political and scientific agenda in an intensive way that promote hopelessness in citizens, causing risky behaviors such as exposure to COVID-19 in enclosed places. Or, they promote risk prevention compatible with confinement and distancing, but close to hopelessness rather than deliberation and planning of detection tests, vaccination, use of masks, alcohol gel, or oximeters.

Unlike the rational choice theory that focuses on the usefulness of available information and the forward-looking attitude theory that focuses on the certainty of information, reasoned action theory assumes that information is a general environment that will influence behavior to the extent that the information is transformed into rules (Quiroz et al., 2019). This is because the theory of reasoned action considers that all information is a cognitive process (Garibaldi et al., 2021). Therefore, an overview of the environment, its demands and favorable opportunities suggest intermittent decisions and actions. A situational perspective defines objectives, tasks, and defined goals. Categories of accessible and abundant information availability that will influence wasteful behavior, such as believing that jobs, salaries, and financial 
credit increase significantly (Moreno et al., 2019). On the contrary, if the context is rather recessive and of economic crisis, then austere, cooperative, and innovative lifestyles will be adopted.

However, the theory of reasoned action, like the theory of rational choice and the theory of prospective attitude, pose a predictive scenario of a specific behavior without considering the current situation and without specifying who makes the decision (Bolívar et al., 2019). The rational choice assumes that the context can be reduced to information disseminated in the media without assuming the seg- mentation of audiences. The reasoned action theory warns that the available information is enough reason for decision making. The forward-looking attitude assumes that risk coexist with earnings expectations, reaching an informative balance for exposure to threats.

\section{Methodology}

A documentary work was done with a selection of sources and international repositories such as Scopus and WoS, considering the keywords "specification" and "intellectual capital" in the period 2019 to 2021 (see Table 1).

Table 1

Descriptive Sample

\begin{tabular}{|c|c|c|c|c|c|c|c|c|c|}
\hline & \multicolumn{4}{|c}{ C1 } & \multicolumn{3}{c|}{ C2 } & \multicolumn{3}{c|}{ C3 } \\
\cline { 2 - 11 } & $\mathbf{2 0 1 9}$ & $\mathbf{2 0 2 0}$ & $\mathbf{2 0 2 1}$ & $\mathbf{2 0 1 9}$ & $\mathbf{2 0 2 0}$ & $\mathbf{2 0 2 1}$ & $\mathbf{2 0 1 9}$ & $\mathbf{2 0 2 0}$ & $\mathbf{2 0 2 1}$ \\
\hline Academia & 1 & 3 & 3 & 1 & 3 & 2 & 3 & 5 & 4 \\
\hline Conacyt & 3 & 2 & 2 & 3 & 2 & 1 & 2 & 4 & 3 \\
\hline Copernicus & 4 & 1 & 1 & 2 & 1 & 3 & 1 & 3 & 5 \\
\hline Dialnet & 5 & 4 & 4 & 1 & 3 & 4 & 3 & 4 & 4 \\
\hline Dimensions & 2 & 3 & 2 & 4 & 2 & 5 & 2 & 5 & 5 \\
\hline Ebsco & 4 & 2 & 1 & 3 & 4 & 4 & 4 & 4 & 4 \\
\hline Frontier & 3 & 4 & 1 & 5 & 5 & 3 & 5 & 3 & 3 \\
\hline Google & 5 & 3 & 1 & 4 & 4 & 2 & 4 & 4 & 4 \\
\hline Latindex & 4 & 5 & 1 & 2 & 5 & 4 & 3 & 4 & 2 \\
\hline Microsoft & 3 & 4 & 2 & 5 & 4 & 5 & 2 & 2 & 3 \\
\hline Redalyc & 3 & 3 & 3 & 4 & 5 & 4 & 4 & 3 & 2 \\
\hline Scielo & 2 & 2 & 2 & 3 & 4 & 3 & 3 & 1 & 1 \\
\hline Scopus & 3 & 4 & 4 & 4 & 3 & 2 & 1 & 2 & 2 \\
\hline Zenodo & 4 & 3 & 2 & 3 & 2 & 1 & 2 & 1 & 1 \\
\hline Zotero & 2 & 2 & 1 & 2 & 1 & 1 & 1 & 1 & 1 \\
\hline
\end{tabular}


A search for abstracts was carried out to obtain the intellectual capital indicators (Garcia et al., 2021). Then, once the indicators of empathy, trust, commitment, entrepreneurship, productivity, competitiveness, innovation, satisfaction, and happiness had been selected, the experts in the field rated these indicators in order of importance-with 10 being the most important and $\mathrm{o}$ being not important (Garza et al., 2021) - , and then processed the data in the statistical analysis package for Social Sciences version 20.0 (Sandoval et al., 2021). Percentages, contingencies, and proportions were estimated to establish risk thresholds in decision making on intellectual capital indicators.

\section{Results}

The confidence indicator obtained the highest percentage (25\%), followed by commitment (22\%), empathy $(17 \%)$, entrepreneurship (13\%), satisfaction (9\%), innovation (6\%), productivity (4\%), competitiveness (3\%), and happiness ( $1 \%$ ). This means that decision making is a function of the level of trust, although the instrument does not specify the type of trust, which can be organizational, interpersonal, intrapersonal, or technological.

In order to be able to estimate the axes, trajectories, and relationships among the three search categories with respect to the selected summaries, we proceeded to establish their normality, linearity, adequacy, sphericity, and homoscedasticity, considering the distribution parameters, as well as the coefficients of multivariate analysis (see Table 2).

Regarding the relationships between the categories, the correlation and covariance matrix was estimated, considering that human, social, and intellectual capital are related to being included in knowledge management. This is so because in the face of the confinement and distancing of people, the virtual classroom works as an informative self-management instrument, as well as data processing based on academic, professional, and labor training criteria. This social capital is linked to human capital for its academic biosafety as prevention of accidents, infection, disease, and death. In this process, human capital is specialized and updated according to the communication of risks regarding COVID-19 (see Table 3).

The probability proportions suggest that the intellectual capital creation process, centered on intrapersonal confidence in abilities $[\mathrm{OR}=17.21(13.24-19.20)]$, abilities $[\mathrm{OR}=18.21(14.35-20,21)]$, knowledge [OR $=15.43(13.24-21.23)]$, experiences $[\mathrm{OR}=$ 18.20 (14.32- 23.45)], and emotions [15.46 $(10,21$ at 22.31)], is at an admissible risk threshold. It means, then, that the intervention of social work can be based on the creation of intellectual capital and its intrapersonal trust indicators. Having established the relationships between the categories, we proceeded to estimate the structure of axes, paths, and relationships 
Table 2

Descriptive Instrument

\begin{tabular}{|c|c|c|c|c|c|c|c|c|c|}
\hline \multirow[t]{2}{*}{ A } & \multicolumn{3}{|c|}{ C1 } & \multicolumn{3}{|c|}{ C2 } & \multicolumn{3}{|c|}{$\mathrm{C}_{3}$} \\
\hline & $\mathrm{M}$ & SD & $K$ & $M$ & SD & $\mathrm{K}$ & $\mathrm{M}$ & SD & $\mathrm{K}$ \\
\hline a1 & 2.5 & .45 & 1.4 & 2.4 & .54 & 1.3 & 2.5 & .45 & 1.4 \\
\hline$a 2$ & 2.6 & .54 & 1.9 & 2.3 & .68 & 1.0 & 2.4 & .43 & 1.6 \\
\hline a3 & 2.9 & .65 & 1.0 & 2.4 & .64 & 1.1 & 2.6 & .53 & 1.4 \\
\hline a4 & 2.3 & .46 & 1.7 & 2.8 & .53 & 1.3 & 2.5 & .63 & 1.0 \\
\hline a5 & 2.1 & .53 & 1.3 & 2.4 & .42 & 1.8 & 2.0 & .47 & 1.3 \\
\hline a6 & 2.5 & .47 & 1.4 & 2.0 & .43 & 1.7 & 2.5 & .58 & 1.2 \\
\hline a7 & 2.4 & 4.8 & 1.6 & 2.3 & .57 & 1.3 & 2.4 & .59 & 1.4 \\
\hline a8 & 2.0 & .54 & 1.3 & 2.1 & .69 & 1.4 & 2.2 & .60 & 1.7 \\
\hline a9 & 2.4 & .53 & 1.2 & 2.2 & .51 & 1.5 & 2.0 & .65 & 1.9 \\
\hline a10 & 2.6 & .52 & 1.4 & 2.3 & .65 & 1.3 & 2.9 & .67 & 1.3 \\
\hline a11 & 2.7 & .55 & 1.9 & 2.4 & .62 & 1.2 & 2.7 & .66 & 1.2 \\
\hline a12 & 2.3 & .56 & 1.3 & 2.4 & .59 & 1.4 & 2.8 & .45 & 1.1 \\
\hline a13 & 2.4 & .50 & 1.0 & 2.8 & .35 & 1.3 & 2.4 & .48 & 1.5 \\
\hline a14 & 2.7 & .59 & 1.3 & 2.3 & .46 & 1.6 & 2.5 & .43 & 1.4 \\
\hline a15 & 2.9 & .46 & 1.2 & 2.9 & .41 & 1.3 & 2.3 & .41 & 1.7 \\
\hline a16 & 2.4 & .41 & 1.1 & 2.3 & .51 & 1.3 & 2.4 & .43 & 1.5 \\
\hline a17 & 2.1 & .48 & 1.3 & 2.1 & .61 & 1.2 & 2.4 & .50 & 1.8 \\
\hline a18 & 2.9 & .43 & 1.7 & 2.9 & 60 & 1.1 & 2.1 & .52 & 1.3 \\
\hline
\end{tabular}

Note: Elaborated with data from the study. C1 = Human Capital, C2 = Social Capital, C3 = Intellectual Capital, $\mathrm{A}=$ Abstract, $\mathrm{M}=$ Mean, $\mathrm{SD}=$ Standard Deviation, $\mathrm{K}=$ Kurtosis.

Table 3

Correlation and Covariance Matrix

\begin{tabular}{|c|c|c|c|c|c|c|c|c|c|}
\hline & $\mathbf{M}$ & SD & $\mathbf{K}$ & $\mathbf{C 1}$ & $\mathbf{C 2}$ & $\mathbf{C 3}$ & $\mathbf{C 1}$ & C2 & C3 \\
\hline C1 & 24.32 & 14.35 & 1.452 & 1.000 & & & 1.657 & .543 & .632 \\
\hline C2 & 21.35 & 10.54 & 1.098 & $.672^{\star}$ & 1.000 & & & 1.834 & .476 \\
\hline C3 & 26.54 & 16.56 & 1.564 & $.436^{\star *}$ & $.562^{*}$ & 1.000 & & & 1.982 \\
\hline
\end{tabular}

Note: Elaborated with data from the study. C1 = Human Capital, C2 = Social Capital, C3 = Intellectual Capital, $\mathrm{M}=$ Mean, $\mathrm{SD}=$ Standard Deviation, $\mathrm{K}=$ Kurtosis. * $\mathrm{p}<.01 ;{ }^{* \star} \mathrm{p}<.001 ;{ }^{* \star *} \mathrm{p}<.0001$. 
between human, social, and intellectual capital, considering that these categories were reflected in summaries published in the repositories consulted, as well as their configuration in a research agenda which is distinguished by alluding to the three types of capital before the COVID-19 (see Figure 1).

The contingency parameters suggest significant differences between the decisions made based on intrapersonal versus interpersonal trust [ $\varkappa_{2}=16.27(16 \mathrm{df})$ $\mathrm{p}>$.05; GFI $=.997$; CFI $=.990 ; \mathrm{RMR}=$ .006]. In other words, as an educational process, intellectual capital focuses on internal capacities, experiences, skills, knowledge, and emotions rather than outsourcing it when it comes to socializing knowledge. In a formative sense, intellectual capital is limited to internal and external academic relationships without diminishing educational institutions.

\section{Discussion}

The establishment of the agenda, the framing of the repositories and their verisimilitude and verifiability effects reported in the literature up to August 2021 suggest a creation of human and intellectual capital based on issues related to distancing and confinement as preventive strategies and attributable to the State (García Lirios, 2021). This is so because the research agenda complements the political agenda in terms of the containment and mitigation strategies of the pandemic, which is estranged from the self-care of students, professionals, and workers who see their contribution to the pandemic as distant and government interference close.

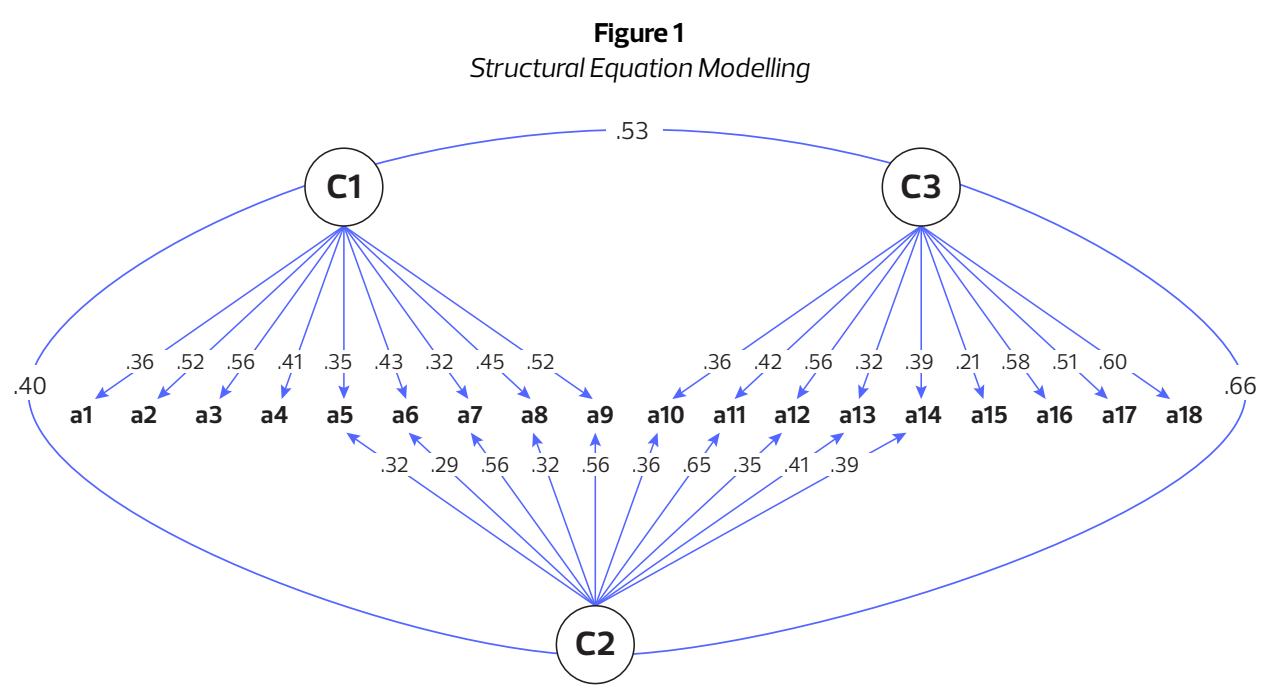

Note: Elaborated with data from the study. C1 = Human Capital, C2 = Social Capital,

C3 = Intellectual Capital, A = Abstracts. 
The public agenda disseminated on issues related to risk communication is made up of plausibility frames (Sanchez et al., 2021). These are strategies that the State adopts and implements based on images; even when they are statistical projections, general data prevail and are even comparable with other data from different or similar countries. This plausibility trick legitimizes the strategies of distancing and confinement, but inhibits the discussion of underreported cases of infection, disease, and death that would question risk communication.

Research lines around discussion, consensus, and co-responsibility between political and social actors, as well as public and private actors, will allow progress towards the construction of a public and common agenda among the parties involved (Molina et al., 2020). Even examining the data rather than its illustrations would allow us to move towards an agenda of central issues around the pandemic. This is the case of the implementation of confinement or social distancing strategies in areas that have been identified as less prone to the concentration of virus. Or, the use of mouth covers in areas identified with high concentrations of particles. Therefore, it is necessary to inquire about the effects of the data illustrated in graphs versus the data that shows the effectiveness of risk communication, or sources that do not come from the State and have gation and containment policies of the pandemic. The repositories that index journals based on the quality of their products and processes would be valid, self-correcting, and reliable sources.

In both scenarios-framing of plausibility and verifiability-the literature published during the pandemic opens the discussion about the influence of risk communication on decisions and actions of distancing and confinement (Garcia et al., 2019). An increase in studies on the plausibility of the pandemic and containment mitigation policies will contribute to the discussion, agreements, and joint responsibilities between the parties and not only to the legitimacy of the State.

The contribution of this work to the state of the art lies in the concretion of a model for the study of intellectual capital, considering the dimensions of intrapersonal trust in which there are skills, emotions, experiences, and knowledge, in the qualification of experts, were located at tolerable risk thresholds.

In relation to the literature where intellectual capital is approached from non-training organizational dimensions such as cooperation, tasks, goals, objectives, or innovations, this work suggests complementing these dimensions with intrapersonal factors to establish differences between professional training and job training. Future lines of research 
on the structural models of intellectual capital, human capital, and social capital will make it possible to establish a predictive explanation of academic, professional, and labor training. The importance of consolidating a comprehensive pedagogical model lies in the innovation of teaching-learning.

Since the information is not available or its actionable actors require immediate planning of their actions, the determinants of planned behavior are those in which the information can be delimited and specified based on a particular situation or for an event which is the subjective control of the decision-making and the available and actionable information. The theory of planned behavior finds that perceived control is a significant determinant of behavior in direct and indirect ways. Interacting with subjective norms and attitudes generates an intention that is also assumed as a determinant of behavior.

However, it is perceived as control, since the norm and attitude depend on a set of beliefs about the availability of information. In this sense, the specification of a model could include variables that anticipate behavior, but not of the beliefs of the availability of information, but of the willingness to cooperate on the part of actors that create a business project to develop their skills, not only of choice, deliberation, or planning, but innovation.

\section{Conclusion}

The creation of human, social, and intellectual capital entails a process of social distancing and confinement where contents oriented towards self-management of knowledge prevails. The published literature is distinguished by including structured summaries with information that allows the follow-up of the findings, as well as their comparison and processing. In other words, the virtual classroom is distinguished from the traditional classroom by the degree of self-management that internet users dedicate to learning structured content for the processing of results. 


\section{REFERENCES}

Aguilar-Fuentes, J. A., García-Lirios, C., Bermúdez-Ruiz, G., Pérez-Ortega, M. I., Bolivar-Mojica, E., de Nava Tapia, S. L., \& Pérez-Crisanto, G. (2019). Especificación de un modelo para el estudio de la percepción de utilidad. Revista de Comunicación y Salud, 9(2), 47-54. https://doi.org/10.35669/revistadecomunicacionysalud.2019.9(2).47-54

Alvarado-Garibaldi, S., Carreón-Guillén, J., \& García-Lirios, C. (2021). Modeling of the mobility habitus in the public transport system with low $\mathrm{CO}_{2}$ emission mechanics in the center of Mexico. Advances in Mechanics, 8(2), 82-95.

Bermudez-Ruiz, G., Sanchez-Rosales, R., Espinoza-Morales, F., Martinez-Munoz, E., Sanchez-Sanchez, A., \& Garcia-Lirios, C. (2019). Meta-Analytical Validity of the Social Entrepreneurship Inventory: A Study of Random Effect Sizes. Global Journal of Management And Business Research. https://journalofbusiness.org/index.php/GJM$\mathrm{BR} /$ article/view/2849

Bolívar, E., Bustos, J., \& García, C. (2019). Specification of a model for the study of entrepreneurial migratory flows. Cinzontle, 10(1), 4-16.

Bustos-Aguayo, J. M., García-Lirios, C., \& Juárez-Nájera, M. (2020). Percepción de seguridad frente a la COVID-19: Security perception against COVID-19. Revista de Investigación Académica Sin Frontera: División de Ciencias Económicas y Sociales, (34)13, 1-28. https://doi. org/10.46589/rdiasf.vi34.343
Bustos, J., López, S., \& García, C. (2019). Discursos de la formación investigativa del capital intelectual en ciencias de la salud. Revista de Psicología de la Universidad Autónoma del Estado de México, 8(16), 823. http://doi. org/10.36677/rpsicologia.v8i16.14931

Carreón, J. (2021). Modelling intellectual capital in the Covid-19 era. Turkish Journal of Computer and Mathematics Education, 12(13), 5497-5506.

Carreón, J., De la Cruz, P., López, S., Alvarado, S., Amemiya, M., \& García, C. (2021). Confirmatory Factor Structure of Treatment Adherence in the COVID-19 Era. Journal of Infectious Diseases \& Case Reports. https://doi. org/10.47363/JIDSCR/2021(2)134

García, C. (2018). Especificando un modelo de representaciones del capital humano en la vejez, juventud e infancia. $R e$ vista CIFE: Lecturas de Economía Social, 2o(32), 167-175. https://doi. org/10.15332/22484914.4860

García, C., Martínez, E., Molina, H. D., \& Hernández, J. (2019). Specification of a self-care model. Lux Médica, 14(42), 1525. https://doi.or$\mathrm{g} / 10.33064 / 42 \operatorname{lm} 20192244$

García, C. (2020). Metaanálisis dimensional de la confianza: implicaciones para la comunicación social de la COVID-19. CITAS, 6(1). https://doi. org/10.15332/24224529.6233

García, C. (2021). Bioseguridad y ciberseguridad percibidas ante la COVID19 en México. Estudios en Seguridad y Defensa, 16(31), 137160. https://doi. org/10.25062/1900-8325.293 
García, C. (2021). Percepciones de riesgos laborales en la era post COVID-19. Know and Share Psychology, 2(1), 1-7.

García-Lirios, C. (2021). Metaanálisis de la seguridad percibida en el transporte público en la era Covid-19. Eco Matemático, 12(1). https://doi. org/10.22463/17948231.3073

García, C., Bolívar, E., Blaness, A., Coronado, O., \& Molina, M. (2021). CONTRASTE UN MODELO DE VIOLENCIA DOMÉSTICA EN LA ERA DEL COVID-19. Revista de Investigación Académica Sin Frontera: División de Ciencias Económicas y Sociales, (35)14, 13. https:// doi.org/10.46589/rdiasf.vi35.379

García, C., Hernández, J., \& Molina, M. (2021). Modelling the perception of security in the Covid-19 era. Revista De Investigación Académica Sin Frontera: División De Ciencias Económicas Y Sociales, (36). https://doi.org/10.46589/ rdiasf.vi36.411

García-Lirios, C. \& Bustos-Aguayo, J. M. (2021). Diseño y evaluación de un instrumento para medir el uso de internet en la era COVID-19. Revista CEA, 7(14), e1665. https://doi. org $/ 10.22430 / 24223182.1665$

García, C., Carreon, J., \& Sanchez-Garza, J.A. (2021). Modeling the Perception of Public Safety. Public Security \& Public Order, 26(1), 81-93.

Garza-Sanchez, J. A., Campos, L. L., \& García, C. (2021). Specification of a Model of Agenda effects, Framing, Priming, and Water Melding. Asian Journal of Education and Social Studies, 16(4), 33-36.
Hernández, J., Juárez, M., Molina, H., Amemiya, M., Garcia, C., et al. (2020) Specification of a Social Intervention Model Against COVID-19. Biomed J Sci \& Tech Res, 26(3). BJSTR. MS.ID.004366.

Hernández, J., Bermudez, G., \& García, C. (2021). Perception of Police Performance in Street around Biosecurity. Public Security \& Public Order, 27(1), 49-61.

Juárez, M., Bustos, J. M., Carreón, J., \& García, C. (2020). La percepción de riesgo en estudiantes universitarios ante la propagación del coronavirus SARSCOV-2 y la enfermedad COVID-19. Revista De Psicología de la Universidad Autónoma del Estado de México, 9(17), 94-107. DOI: https://doi. org/10.36677/rpsicologia.vgi17.15223

Korstanje, M., García, C., Quintero-Soto, L., Campas, C., Barrera, A., García-Espinoza, L., \& Espinoza, F. (2020). International Journal of Engineering Technology and Management Research, Academic Framework of Knowledge Management. 10.13140/ RG.2.2.34865.12647.

Molina, H. D., Garcia, M., García, M. L., Carreón, J., \& García, C. (2020). Una aproximación estadística al comportamiento de brote de COVID-19 en la China continental. Tepexi, 7(14), 1-11.

Morales, F., Sánchez, A., Valdés, J., \& García, C. (2020). Scenarios, phases, roles, and discourses of internet violence in a higher education institution. SUMMA. Revista disciplinaria en ciencias económicas y sociales, 2(1), 65-82. 
Moreno, E., Ferrusca, F., Balderas, W., Vázquez F., Bello, J.M., Ugarte, A., \& García, C. (2019). Governance of Social Representations of Quality of Life. Psychology \& Psychological Research International Journal, 4(4), 1-5.

Quintero, M.L., Lopez, S., Limon, G., Velez, S.S., \& Garcia, C. (2021). Subjective Well-Being in the COVID-19 Era. HUMAN, 1(1), 1-11.

Quiroz, C. Y., García, C., Molina, M. del R., \& Carreón, O. I. (2020). Confiabilidad $\mathrm{y}$ vigencia de un instrumento que mide el emprendimiento en comerciantes del centro de México. Investigación \&Amp; Desarrollo, 28(2), 6-21. https://doi.org/10.14482/indes.28.2.338.04

Sánchez-Sánchez, A. (2019). Specification of a model for the study of management culture. Espirales Revista Multidisciplinaria de Investigación, 3(31), 111. https://doi.org/10.31876/er.v3i31.688

Sandoval, F., Bustos, J. M., \& Garcia, C. (2021). Desarrollo local en la era post COVID-19. Ciencia Huasteca, Boletín Científico de la Escuela Superior de Huejutla, 9(18), 17-22.

Velázquez, A., García, L., Zainos, M., \& García, C. (2020). Specification of a local entrepreneurship model. Revista de Investigación Académica Sin Frontera: División de Ciencias Económicas y Sociales, (33), 1-16. https://doi. org/10.46589/rdiasf.vi33.352

Zallas Esquer, L., Bustos Aguayo, J., Quiroz Campas, C., \& Espinoza Zallas, E. (2020). Salud ocupacional en estudiantes antes del COVID 19: Occupational Health in Students before COVID 19. Revista de Investigación Académica sin Frontera: División de Ciencias Económicas y Sociales, (34). https://doi.org/10.46589/rdiasf. vi34. 358 